\title{
Experimental studies on vegetable marrow seeds ozonation using laboratory equipment
}

\author{
Andrey V. Bogdanov ${ }^{1}$, Victoria $V$. Evchenko ${ }^{1}$, and Svetlana Yu. Popova ${ }^{1, *}$ \\ ${ }^{1}$ FSBEI HE South U ral State A grarian University, 454080, Chelyabinsk, Russia
}

\begin{abstract}
A set of measures is taken to protect plants against various diseases and to prevent yield losses. One of the components of such actions is a pre-sowing seed treatment. One of the effective ways of pre-sowing treatment is seeds ozonization, which stimulates their germination and provides the prevention of plant diseases, hence this process increases the germination and the yield of agricultural crops. Our laboratory equipment was made to substantiate the ozonation regimes. Experimental studies on seeds ozonation were carried out for agricultural crop (the zucchini variety Zebra), which is widely used in Russia, particularly in the natural-climatic areas of the Urals. Taking into account that high ozone concentrations are dangerous to human health and life (to service personnel), pre-sowing seeds treatment was carried out at relatively safe concentrations (up to $10 \mathrm{mg} / \mathrm{m}^{3}$ ), paying attention to the tightness of the equipment. Ozone concentrations of $3 \mathrm{mg} / \mathrm{m}^{3}, 6 \mathrm{mg} / \mathrm{m}^{3}$ and $9 \mathrm{mg} / \mathrm{m}^{3}$ and seed treatment time of $120 \mathrm{~min}, 240$ $\min , 360 \mathrm{~min}$ and $480 \mathrm{~min}$ were chosen. The experimental studies have shown, that a rational regime of seeds treatment for obtaining the maximum germination (79.1\%), is observed when ozone concentration is $9 \mathrm{mg} / \mathrm{m}^{3}$ and treatment time is $247.7 \mathrm{~min}$. Thus, the developed laboratory equipment hel ps to determine the rational ozonation regimes for zucchini seeds. It can also be used to determine the rational ozonation regimes for seeds of other crops.
\end{abstract}

\section{Relevance}

A t present, a set of measures is taken to protect plants from various diseases acquired mainly through infected seed material and thus to prevent yield losses [1-11]. This set of measures includes pre-sowing seeds treatment. A ccording to the results of numerous studies, seeds ozonation is one of the effective ways of pre-sowing treatment [12-20]. This process stimulates seeds germination, it helps to prevent and to treat diseases, it ensures plants protection, and thereby it increases the germination and the yield of agricultural crops.

To substantiate the ozonation regimes, special laboratory equipment for seed ozonation was made in South Ural State Agrarian U niversity at the Department "Processing of agricultural products and life safety" [21].

\footnotetext{
${ }^{*}$ Corresponding author: vetochka.79@ mail.ru
} 


\section{Test object and equipment}

A the initial stage the experimental studies on seeds ozonation were carried out using a crop (the zucchini variety Zebra), which has been widely used in Russia in the natural-climatic area of the Urals.

Considering that ozone is dangerous to human heal th and life (to service personnel), presowing seeds treatment was carried out at relatively safe concentrations of ozone (up to 10 $\mathrm{mg} / \mathrm{m}^{3}$ ) while paying attention to the tightness of the equipment. Ozone concentrations of 3 $\mathrm{mg} / \mathrm{m}^{3}, 6 \mathrm{mg} / \mathrm{m}^{3}$ and $9 \mathrm{mg} / \mathrm{m}^{3}$ and seeds treatment time of $120 \mathrm{~min}, 240 \mathrm{~min}, 360 \mathrm{~min}$ and 480 min were chosen.

W hen conducting experiments, seeds were placed in Petri dishes (four samples of 50 seeds each). The control group was not exposed to ozone treatment (treatment time was 0 minutes). Seed germination after ozonation was determined according to state standard (GOST) 12038-84 "A gricultural seeds. M ethods for determination of germination" [22].

The research results show that when ozone concentrations are $3 \mathrm{mg} / \mathrm{m}^{3}$ and $6 \mathrm{mg} / \mathrm{m}^{3}$, the germination of zucchini seeds practically does not increase as compared with the control group of seeds that were not treated with ozone. W hen ozone concentration was $9 \mathrm{mg} / \mathrm{m}^{3}$, a significant increase in the germination of zucchini seeds was identified. Therefore, the summary Table 1 presents the results of experimental studies of the zucchini seeds (the variety Zebra) when ozone concentration is $9 \mathrm{mg} / \mathrm{m}^{3}$.

Table 1. The results of experimental studies of the zucchini seeds (the variety Zebra) when ozone concentration is $9 \mathrm{mg} / \mathrm{m}^{3}$

\begin{tabular}{|l|c|c|c|c|c|}
\hline Seeds treatment time & $\begin{array}{c}\text { Total } \\
\text { amount of } \\
\text { seeds, pcs. }\end{array}$ & $\begin{array}{c}\text { A mount of } \\
\text { seeds with } \\
\text { sprouts, } \\
\text { pcs. }\end{array}$ & $\begin{array}{c}\text { Germina- } \\
\text { tion, \% }\end{array}$ & $\begin{array}{c}\text { The average } \\
\text { height of } \\
\text { sprouts on the } \\
\text { 10th day, cm }\end{array}$ & $\begin{array}{c}\text { The average } \\
\text { width of the leaf } \\
\text { plate on the 10th } \\
\text { day, cm }\end{array}$ \\
\hline $\begin{array}{l}\text { Control group (with- } \\
\text { out seeds treatment } \\
\text { with 0zone), pro- } \\
\text { cessing time is 0 min }\end{array}$ & 200 & 82 & 41.0 & 1.34 & 0.34 \\
\hline $\begin{array}{l}\text { Seeds treatment with } \\
\text { ozone, processing } \\
\text { time is 120 min }\end{array}$ & 200 & 111 & 55.5 & 3.50 & 1.04 \\
\hline $\begin{array}{l}\text { Seeds treatment with } \\
\text { ozone, processing } \\
\text { time is 240 min }\end{array}$ & 200 & 175 & 87.5 & 7.17 & 2.24 \\
\hline $\begin{array}{l}\text { Seeds treatment with } \\
\text { ozone, processing } \\
\text { time is 360 min }\end{array}$ & 200 & 148 & 74 & 5.30 & 1.85 \\
\hline $\begin{array}{l}\text { Seeds treatment with } \\
\text { ozone, processing } \\
\text { time is 480 min }\end{array}$ & 200 & 84 & 42.0 & 4.07 & 1.25 \\
\hline
\end{tabular}

From Table 1 it can be seen that the largest amount of seeds with sprouts (175 seeds) is observed when they are treated with ozone for 240 minutes. In this case the seed germination has a maximum value of $87.5 \%$. When the time of ozonation is $240 \mathrm{~min}$, the highest values of the average sprout height on the tenth day $(7.17 \mathrm{~cm})$ and the average width of leaf plate $(2.24 \mathrm{~cm})$ are al so observed.

For example, Fig. 1 shows containers with the sprouts of seeds on the tenth day from the seeds of the control group (without ozonation) and the seeds treated with ozone when ozone 
concentration is $9 \mathrm{mg} / \mathrm{m}^{3}$ for 120 minutes, 240 minutes, 360 minutes and 480 minutes. As you can see from the photo (Fig. 1), in the first row of four containers, where the seeds from the control group were planted, only two seeds have sprouted. In the second row (seed treatment with ozone for 120 minutes), only one seed has sprouted. In the third row (seed treatment with ozone for $240 \mathrm{~min}$ ) all seeds have sprouted. In the fourth row (seed treatment with ozone for 360 minutes), three seeds have sprouted. In the fifth row (seed treatment with ozone for 480 minutes), two seeds have sprouted. Thus, the most devel oped sprouts are observed in the third row (all seeds have sprouted), when the processing time is 240 minutes.

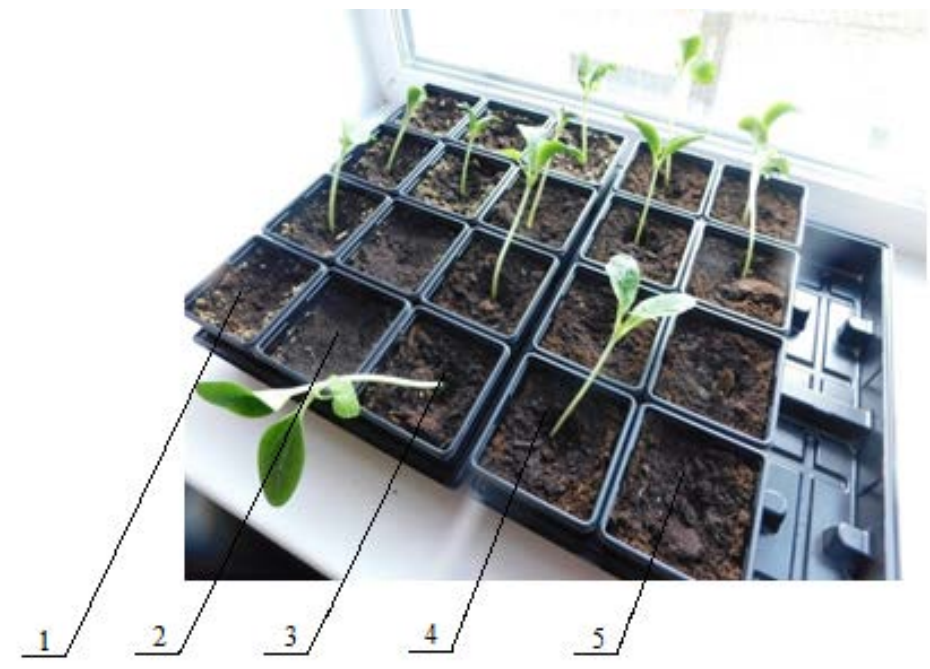

Fig. 1. Containers with sprouts from the seeds of the control group (without ozonation) and the zucchini seeds ( the Zebra variety) treated with ozone when ozone concentration is $9 \mathrm{mg} / \mathrm{m}^{3}$ (from left to right): 1 is a row of four containers with sprouts from the seeds of the control group (without ozonation); 2 is a row of four containers with sprouts from the seeds treated with ozone for 120 minutes; 3 is a row of four containers with sprouts from the seeds treated with ozone for 240 minutes; 4 is a row of four containers with sprouts from the seeds treated with ozone for 360 minutes; 5 is a row of four containers with sprouts from the seeds treated with ozone for 480 minutes

\section{Theoretical substantiation}

Based on the experimental data shown in Table 1 and using M S Excel, we have made a graph of changes in the germination of zucchini seeds depending on the time of their treatment when ozone concentration is $9 \mathrm{mg} / \mathrm{m}^{3}$ (Fig. 2).

The graph shows that with an increase in treatment time, the germination of zucchini seeds of the zucchini variety Zebra increases. At a certain time value, the germination reaches its maximum. Then, if ozonation continues, seed germination decreases.

The regression equation for the experimental curve (Fig. 2) is as follows:

$$
G_{\text {erm }}{ }^{e}=-0.0007 \cdot t_{t r}^{2}+0.3468 \cdot t_{t r}+36.114
$$

where $\mathrm{G}_{\mathrm{erm}}{ }^{\mathrm{e}}$ is the germination value according to the results of the experiment, \%; $t_{t r}$ is the time of seed treatment with ozone, min. 


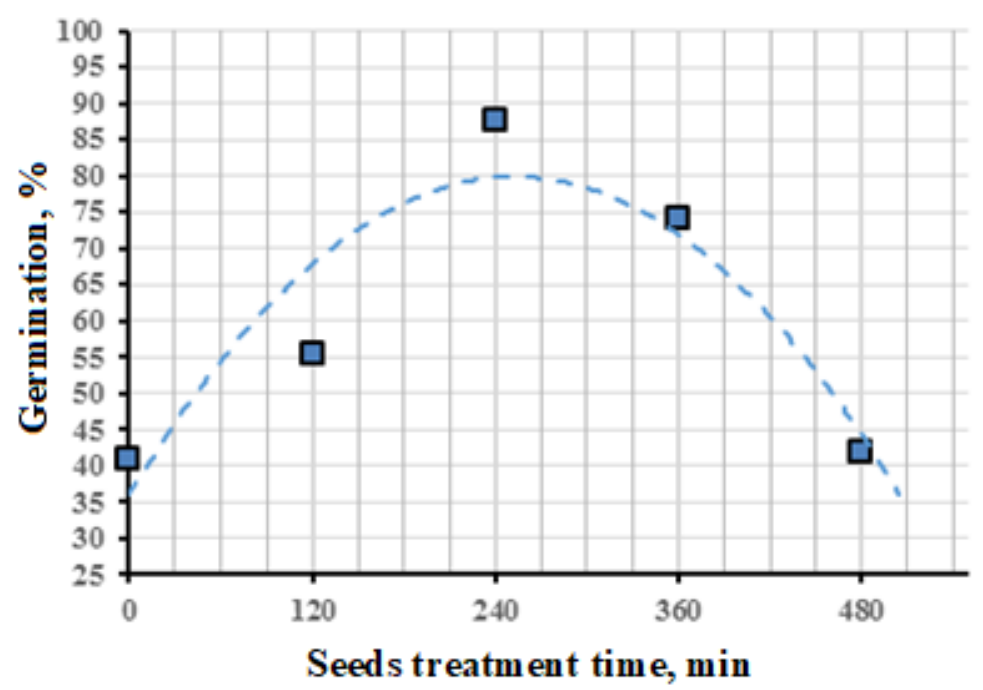

Fig. 2. Dependence of seed germination of the zucchini variety Zebra on treatment time when ozone concentration is $9 \mathrm{mg} / \mathrm{m}^{3}:---$ is the average values according to the regression equation; $\boldsymbol{m}$ is the average values according to the results of the experiment

L et us analyze the expression (1). To determine the extremum of function (1), we find its derivative and equate it to zero:

$$
-0.0014 \cdot t_{t r}+0.3468=0
$$

From the expression (2) we determine the time of seed treatment with ozone $t_{t r}$ with maximum germination ( $t_{t r}=247.7 \mathrm{~min}$ ).

Substituting the determined time value of seed treatment with ozone at maximal germination $t_{t r}=247.7 \mathrm{~min}$ in the expression (1), we get the maximum germination which is equal to $79.1 \%\left(\mathrm{G}_{\mathrm{erm}}{ }^{\mathrm{e}}=79.1 \%\right)$.

\section{Conclusion}

Our experimental studies have shown, that with relatively safe ozone concentrations a rational regime for seed treatment is observed provided the maximum germination rate is $79.1 \%$, the ozone concentration is $9 \mathrm{mg} / \mathrm{m}^{3}$ and the treatment time is 247.7 minutes. Thus, the developed laboratory equipment helps to determine the rational ozonization regimes for zucchini seeds. It can also be used to determine the rational ozonization regimes for seeds of other crops.

\section{References}

1. Cultivation technologies of agricultural crops. Cultivation methods, etc. doi: http://www.neuch.ru/referat/26642.html

2. I.P. Firsov, A .M. Soloviev, M .F. Trifonova, Plant-growing technology, 472 p. (2006)

3. Organic fertilizer, doi: http://ru-ecology.info/term/7560/

4. Crop tending, doi: http://agrolib.ru/rastenievodstvo/item/f00/s02/e0002144/index.shtml.

5. Justification of the timing and methods of harvesting crops, doi: http://www.studfiles.ru/preview/5050014/page:11/

6. N. A. K orlyakova, Agronomy with the basics of botany, 423 p. (1980) 
7. G.V. Gulyaev, A.P. Dubinin, Selection and Seed Production, 352 p. (1987)

8. N.K. Izhik, Field germination of seeds, 200 p. (1976)

9. N.N. K uleshov, Agronomic seed science, 304 p. (1963)

10. Fundamentals of Agronomy, ed. by M .D. A troshenko, 319 p. (1978)

11. V.N. Avdeeva, The use of ecological methods for the suppression of pathogenic microflora of winter wheat grain during storage, thesis of candidate of agricultural sciences (2009)

12. V.N. A vdeeva, Y u.A. Bezgina, Wheat seeds treatment with ozone to increase their sowing qualities, v. 17. No 2. pp. 25-29 (2015)

13. I.V. Gorskiy, Treatment of wheat seeds with ozonized air, thesis of candidate of agricultural sciences (2004)

14. V.N. Ognev, The use of environmentally friendly methods of pre-sowing seed treatment to protect spring barley against root rot, v. 1. pp. 172-176 (2008)

15. V.A. Saveliev, Pre-sowing treatment of grain crops seeds, doi: https://elibrary.ru/item.asp?id=22313821

16. E.K. Saeed, Biological activity of ozone as a disinsection means of stored grain, thesis of candidate of biological sciences (2004)

17. M.A. Sigacheva, The influence of pre-sowing seeds ozonization on the yield and grain quality of spring wheat in the Kuznetsk forest-steppe area, thesis of candidate of agricultural sciences (2015)

18. A.A. Shevchenko, Electro-ozonation parameters for pre-sowing treatment of maize seeds, thesis of candidate of technical sciences (2005)

19. I.V. Shesterin, The effect of ozone and disinfectants on sowing qualities and improvement of spring wheat, synopsis of thesis of candidate of agricultural sciences (2004)

20. Kaufmann technology. Practical use of ozone in crop production, doi: http://www.kaufmanntec.ru/images/present/R astenievodstvo.pdf.

21. A.V. Bogdanov, V.V. Evchenko, V.V. Kolyagin, S.Y u. Popova (2018) Equipment for seeds ozonation, Patent Application No. RUS 186528 РФ МПК ${ }^{7}$ A01C 1/00. Chelyabinsk: South U ral State A grarian U niversity.

22. State standard (GOST) 12038-84 "Agricultural seeds. Methods for determination of germination", doi: https://allgosts.ru/65/020/gost_12038-84 